\title{
Equilibrium
}

Quarterly Journal of Economics and Economic Policy

VOLUME 7 ISSUE 4, 2012

ISSN 1689-765X

Beata Skubiak* $^{*}$

University of Szczecin, Poland

\section{Challenges for Economic Policy IN THE ERA OF ECONOMIC INTEGRATION AND GLOBALIZATION}

\section{JEL Classification Codes: F62}

Keywords: strategy, cohesion policy, integration, globalization

\begin{abstract}
In this article an attempt was made to answer the question of why economic policy must not only perceive the process of globalization and integration, but should also be led in a way which would exploit the opportunities created for the Polish economy by globalization and economic integration. This particularly applies to developing a long-term strategy for socio-economic growth, and implementation of structural policy, which is financed by the European Union.
\end{abstract}

\section{INTRODUCTION}

Science explains that globalization is an interdisciplinary process, a theoretical concept used in many disciplines of science, "the result of combining several factors such as technology, economy and politics. The combination of these factors was a result of the development of global companies, in general the globalization of the economy. International economic relations are becoming extremely important for the countries participating in these processes in the time of globalization and integration. Whether or not certain

(C) Copyright Nicolaus Copernicus University Press

Date of Submission: December 15, 2010; date of acceptance: October 5, 2011

* Contact: e-mail: bskubiak@wneiz.pl, Uniwersytet Szczeciński, Wydział Nauk Ekonomicznych i Zarządzania, ul. Mickiewicza 64, 71-101 Szczecin, Poland 
countries or country groupings become competitive in the world arena, depends primarily on their degree of involvement in international economic relations at regional, continental, global and also institutional level. The implementation of certain economic policy instruments in the international sphere, the growth of innovation, the improvement of human and social capital, increase the harmonious integration between the countries, which raises the level and quality of life in societies, countries and regions.

This article makes an attempt to answer the question of why economic policy must not only perceive the process of globalization and integration, but should also be led in a way which would exploit the opportunities created for the Polish economy by globalization and economic integration. This particularly applies to developing a long-term strategy for socio - economic growth, and implementation of structural policy, which is financed by the European Union.

Globalization of the economy may give opportunities for more open economies, even causing disparities, a sense of mutual interests but, on the other hand, makes the national economy vulnerable to any collapse on world markets, such as the financial meltdown, recession, structural crises, increase in unemployment growth (Smolski, Smolski, Stadtmüllero 1999). The projections for the future global economy are not the same, ranging between optimism, pointing to a chance in the processes of globalization of the economy, and pessimism, coming from the conviction that the economy growth gap will get worse and will lead to an economic war, protectionism and eventually to political-military conflicts. Globalization, which for some is a source of "limitless possibilities", according to others, carries the danger of a new colonization by industrialized countries. The fact is that in industrialized countries there has been a significant increase of the gap between those who benefit from globalization and those who failed to adapt to it. Because of the growth of connections between different aspects of international life and internationalization of markets and capital, acceleration of technology and communications, there is an increase in competitiveness, which creates both tremendous financial and economic opportunities and growing dependence.

Regional integration more or less takes the form of closed institutionalized relationships characterized by mutual economic cooperation. To a large extent added to globalization, although regional integration did not only take it into account, but not expected the changes to such an extent as well. If integration is a deliberately chosen and arbitrarily imposed process, then globalization is largely spontaneous and bottom-up. Integration has to a large extent released the globalization process and with its current state became the answer to the challenges and threats of globalization. Many countries want to be protected in integration blocks in order to feel safer from global 
competition and not always recognizable phenomenon going along with globalization. Regional integration tends to improve market operations, makes it free from internal rules, but in a manner not leading to the weakening of the influence of national states on the economy.

Further in this article two problems will be discussed, which are very important, according to the author and which reduce the Polish chances to get benefits offered by the global economy, and these are: the lack of long-term strategy for socio-economic development and the way of use of European Union funds, with which cohesion policy is financed.

\section{ECONOMIC POLICY AND A SOCIO-ECONOMIC DEVELOPMENT STRATEGY}

Constant concern for competitiveness of the economy determines its growth on international markets. Only well-managed economies have a chance to compete in international markets. In this context, the strategy for socioeconomic development plays a huge role. The strategy for socio-economic development was and still remains a challenge for the times we live in. The strategy for socio- economic development is a setting of specific achievable goals and methods for this development and how it will apply to reaching its objectives, as well as a set of measures that will be used to achieve them. The national strategy has to mobilize the effective use of all local potentials and describe the necessary steps leading to reaching the main objectives in the short, medium and long-term, and predict possible alternative measures. The strategy ought to precede their own and others' actions and economic trends. The Polish economy is still under systemic transformation, despite already creating the foundations for market structure, and the whole process of change is still marked with pathologies of the transitional period (the syndrome of poor countries, inefficient, vulnerable to political instability, with not clearly defined social role, the central authority works in a conceptual vacuum, there are multiple development aims - often contradictory).

Not every document, even if it is called so, is a strategy. A strategy is when several conditions have been met:

- developed diagnosis of the current state including basic problems (needs), the main causes of growth, opportunities and threats and the foundation for the hierarchy or priority-setting;

- there are one or more strategic aims, which have been selected from many possible and wanted;

- the criteria and values which determined the choice and which affect the way of reaching goals have been specified;

- basic ways to realize goals and verified that they are reachable at the time 
given with using available resources have been selected;

- time in which it has to occur, for the strategy has been specified; it is usually a period of 15-25 years with an indication of the tasks done during the first few (e.g. 5-6) years;

- the vision of the future, to which we strive through the realization of the selected goals, with the help of the selected ways in certain time has been defined;

- necessary conditions for cooperation of all subjects and all sectors of national economy at the strategy level have been created;

- strategy proposal has been accepted and adopted by the residents and organizations in the country.

It is clear that the essence of a strategy is to make choices. It is important to find those which are sufficiently general (strategic), necessary and sufficient to achieve the aims, leaving details to the competence of others. There is also a need to reject the temptation to add any unrealistic good intentions to the strategy. Finally, the strategy must be consistent and free from internal contradictions. It should be reachable by such means which are available to us. The strategy is the object of choice and decisions taken by individuals with their responsibility and purpose. Generally speaking, the pattern of long-term strategy did not spread in Poland, and hence did not the strategic thinking, which would ensure that today's decisions are created by the vision of the future of the country tomorrow, where basic role is played by the conditions for acquiring, maintaining and strengthening its position in the markets. At the macro level, this means that the chances of fast growth are available only to those countries which develop long-term creative strategies and aim at developing competitive strategy advantage in the international market. At the micro level, strategic thinking in terms of long-term horizon is to serve the survival and development of the company in the face of tough market competition requirements. Political-constitutional changes taking place in Poland requires thinking and acting in strategic terms, which emphasizes the need for profound changes in the future.

The reduction of the existing growth gap between Poland and the European Union (see Figures 1-7) is possible by providing a growth rate of GDP in Poland which will be significantly ahead of the pace of growth in other EU countries. There is a need for a modern development policy providing a precondition for strategic programming of socio-economic development of the country. At the same time, providing a support for the rational use of funds marked for Polish European Union, and thus arising chances from the Polish membership in the Union. The country's development strategy is to be an expression of such modern development policy which corresponds with the process of globalization and the challenges posed by Europe's renewed Lisbon strategy, which helps to reduce the development gap to the richer 
European Union countries. That policy should use such features of the Polish economy and Polish society that can be a source of comparative advantage for our country, and, thus, a relatively young and increasing number of welleducated professionals, high entrepreneurship of Polish society and the large internal market. The policy should also prevent the widening of disparities in the growth level between regions, in order to avoid the marginalization of the least developing regions. In the first years of systemic transformation in Poland, there was a move away from socio-economic programming on the national level. However since the middle 90's - mainly in connection with the preparations for accession to the European Union and EU requirements plans for the return to strategic public activity were started. In the past few years there were developed more than 200 different kinds of government programs and policies, which greatly exceeded the number of plans created in a similar time frame in a centrally-planned economy. Of course, this sort of renaissance of the method providing the socio-economic policy which was initially rejected, has now been reactivated in an altered form, adapted to the new state's conditions. At the same time, the lack of experience and change of conditions make the process difficult and quantity turns into quality slowly (more: Sulmicka 2004).

The Polish economy needs a socio-economic strategy in order to reach not only the level of old EU countries, but also some new ones, in terms of average GDP per capita. Economic policy requires the development strategy, the setting of the long-term goal and develop the way to reach it. The changes in public finances are the most urgent. The important elements of the strategy should be the completion of privatization and the health system reform. For better development, there is a need for regulatory reform. If Poland is to be successful economically, strengthening reforms for development must be implemented consistently, regardless of who holds power.

The lack of development strategy and common vision of Poland ought to be recognized (without taking into account the backwardness in the eadministration) as the first cause which reduces the chances of Poland to benefit from the opportunities offered by the global economy. If Poland wants to build a modern economy, it should develop a long-term economic strategy. But before activities for development strategy start, there is a question of what the Polish economy is to achieve and how these goals should be achieved (for example, a lot is said about the need to promote and attract technologically advanced investments, which should be one of the pillars of the knowledge-based economy. This is indicated by the assumptions of the "Innovative Economy" operational program. But, in this document, there is not an answer for the question on which foreign investments Poland depends, in which sectors, industries or sectors of the economy, in which areas Polish economy has a chance to really compete with other countries?). The 


\section{2}

priority of investments in human capital should be stressed in the strategy. Using the experience of other countries (e.g. the Czech Republic), the efforts should be focused only on a few selected sectors which will ensure adding value to the economy or to create a list of specific companies (e.g. UK), whose investments are desirable in the country and focus on these companies needed actions (Kanthak 2007).

Figure 1. Long-term unemployment rate

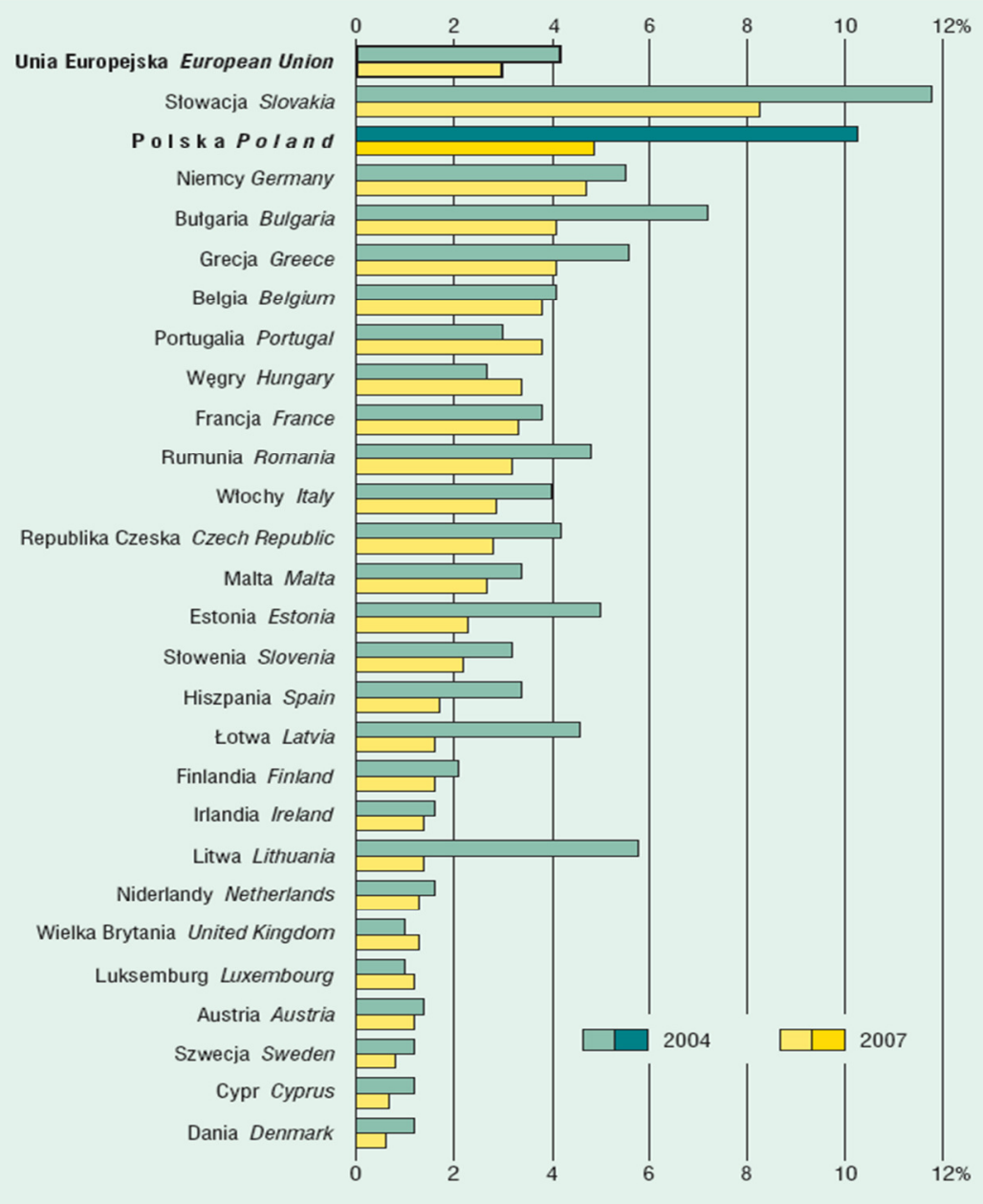

Source: Poland in the European... (2009). 
Figure 2. Import and Exports (thousands of euros)

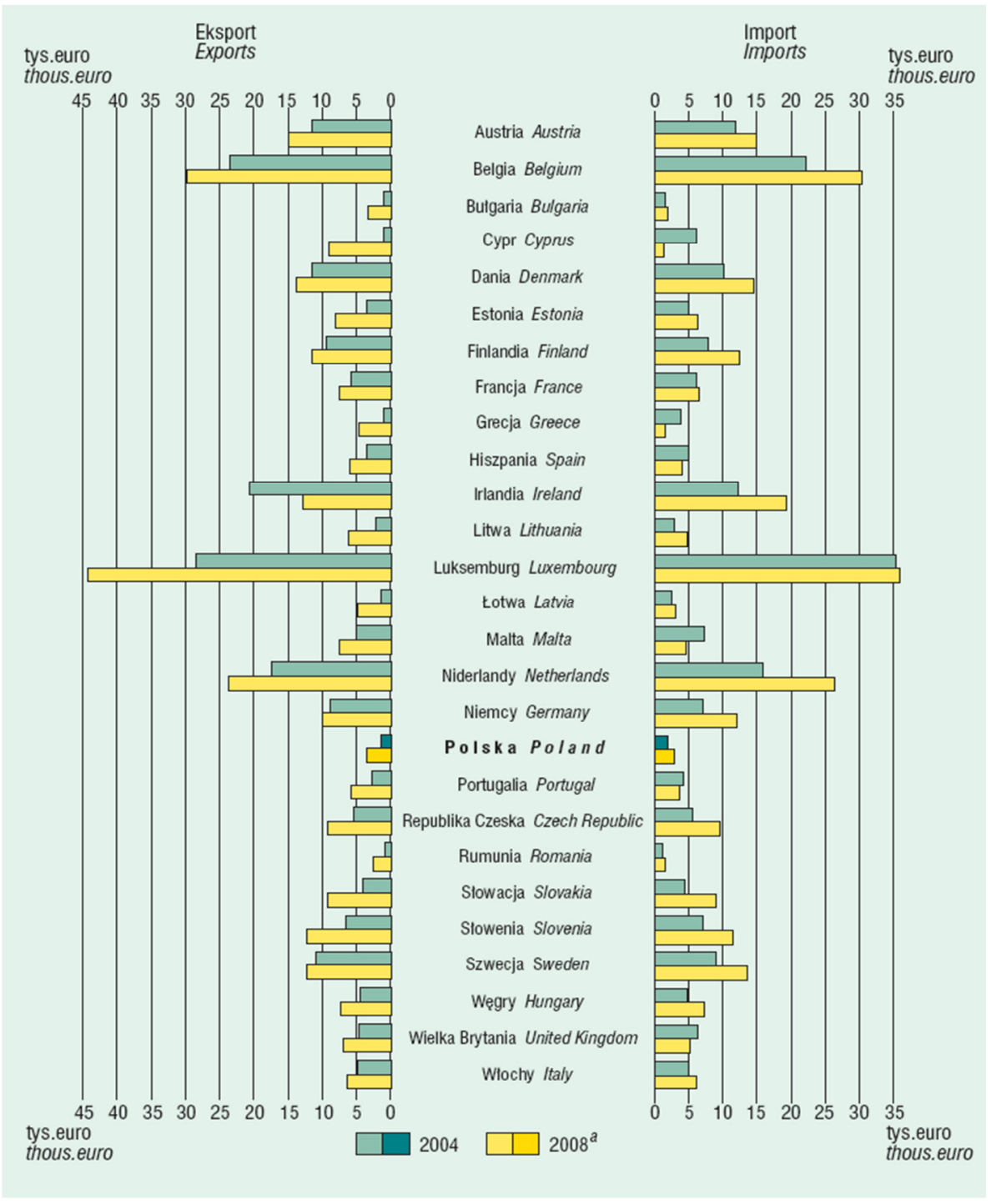

Source: Poland in the European... (2009). 


\section{Beata Skubiak}

Figure 3. GDP in 2008

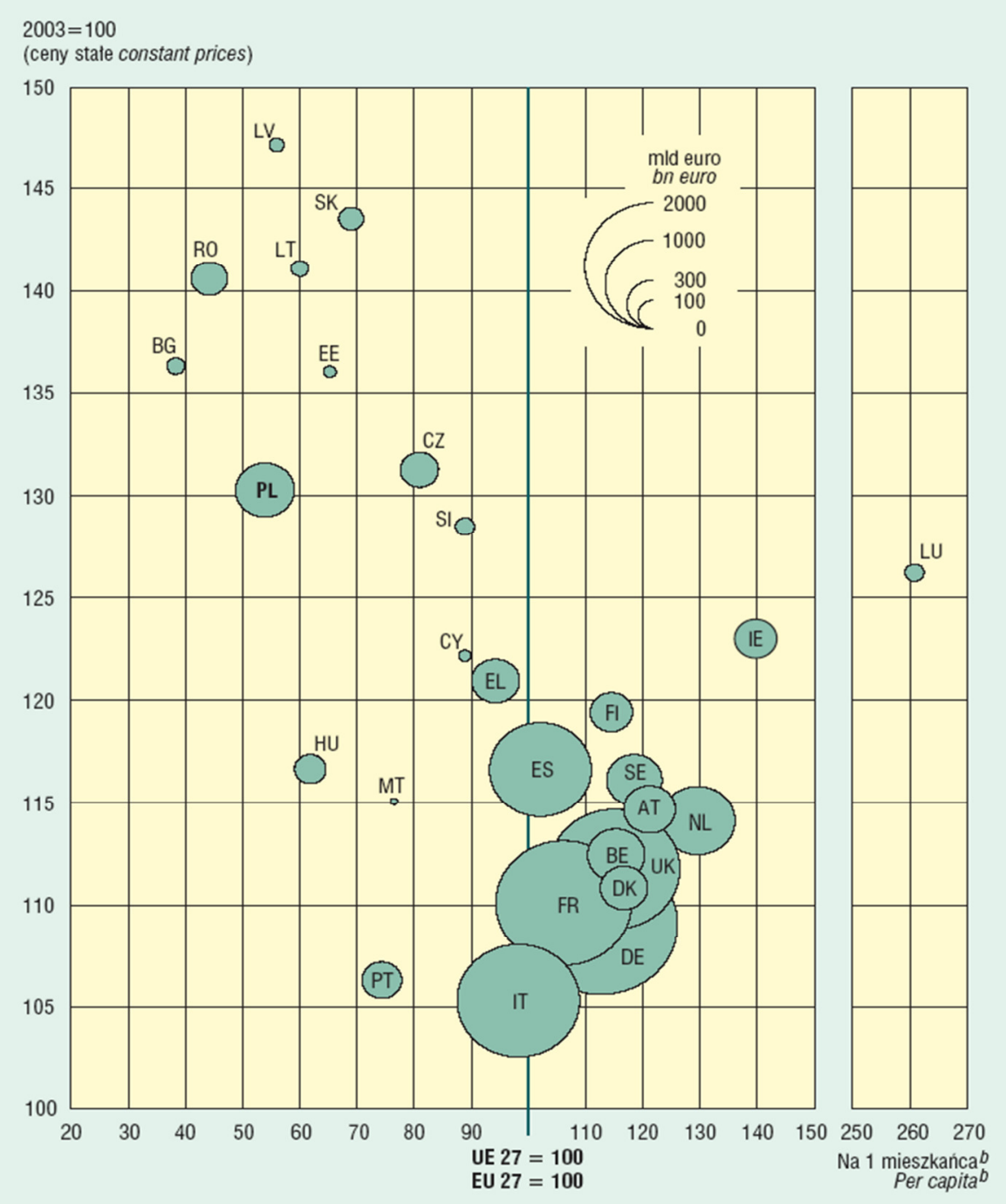

Source: Poland in the European... (2009). 
Figure 4. Labour productivity

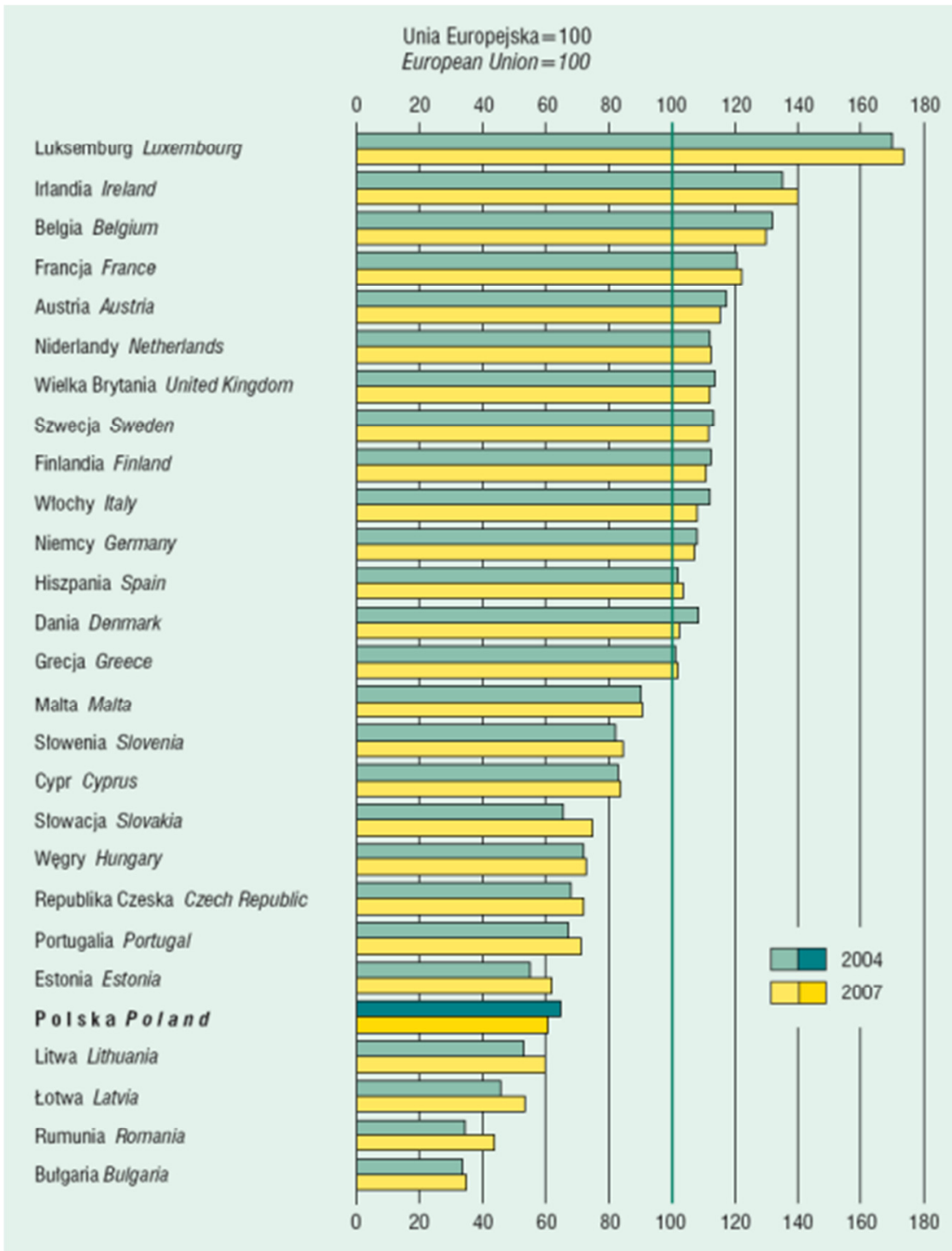

Source: Poland in the European... (2009). 
Figure 5. Expenditures on R \& D to GDP ratio

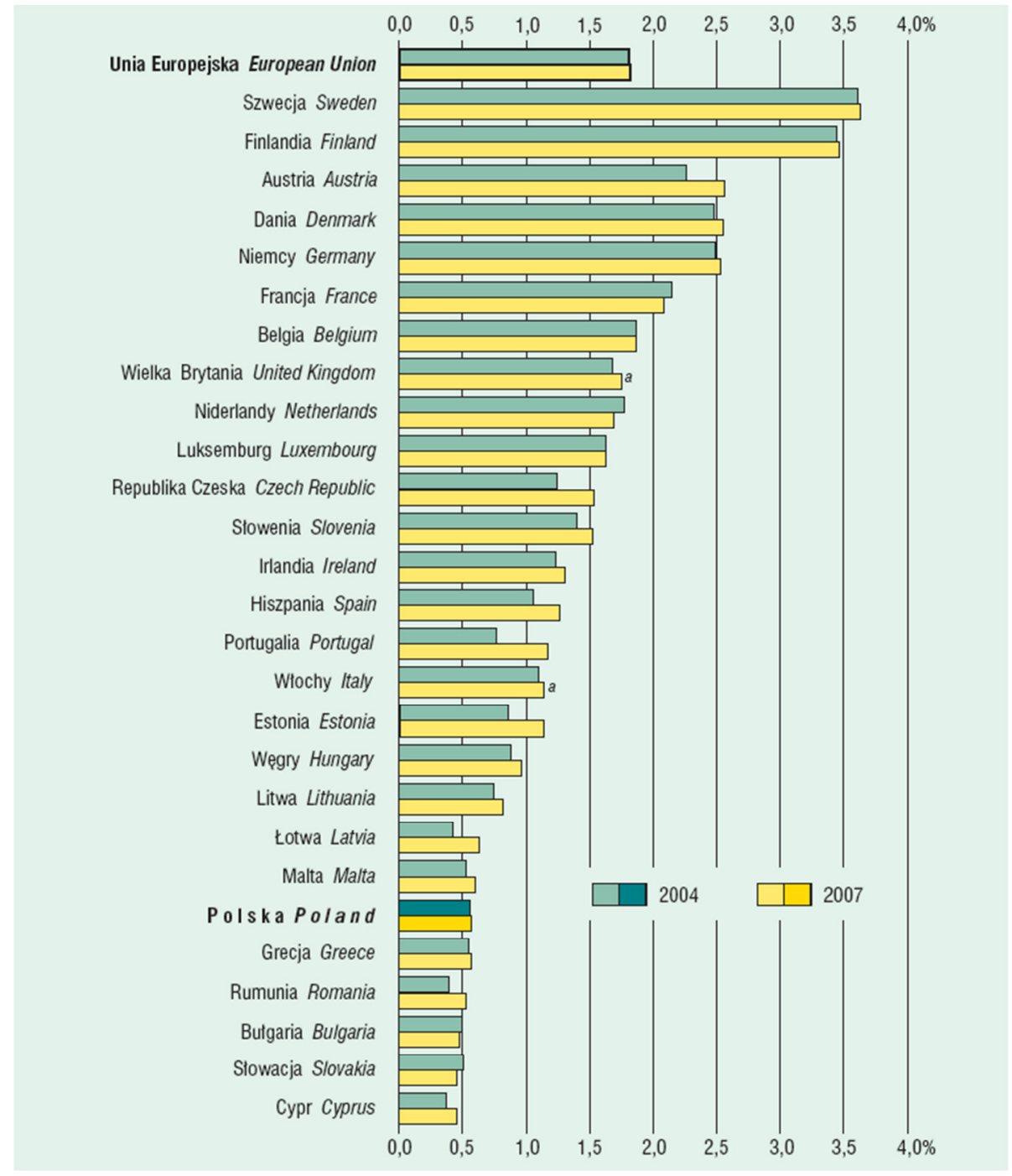

Source: Poland in the European... (2009). 
Figure 6. Internet users per 1000 population

Niderlandy Netherlands

Szwecja Sweden

Luksemburg Luxembourg

Finlandia France

Wielka Brytania United Kingdom

Slowenia Slovenia

Dania Denmark

Estonia Estonia

Rumunia Romania

Wiochy Italy

Bułgaria Bulgaria

Niemcy Germany

Łotwa Latvia

Austria Austria

Belgia Belgium

Francja France

Cypr Cyprus

Hiszpania Spain

Slowacja Slovakia

Republika Czeska Czech Republic

Polska Poland

Węgry Hungary

Litwa Lithuania

Irlandia Ireland

Malta Malta

Portugalia Portugal

Grecja Greece
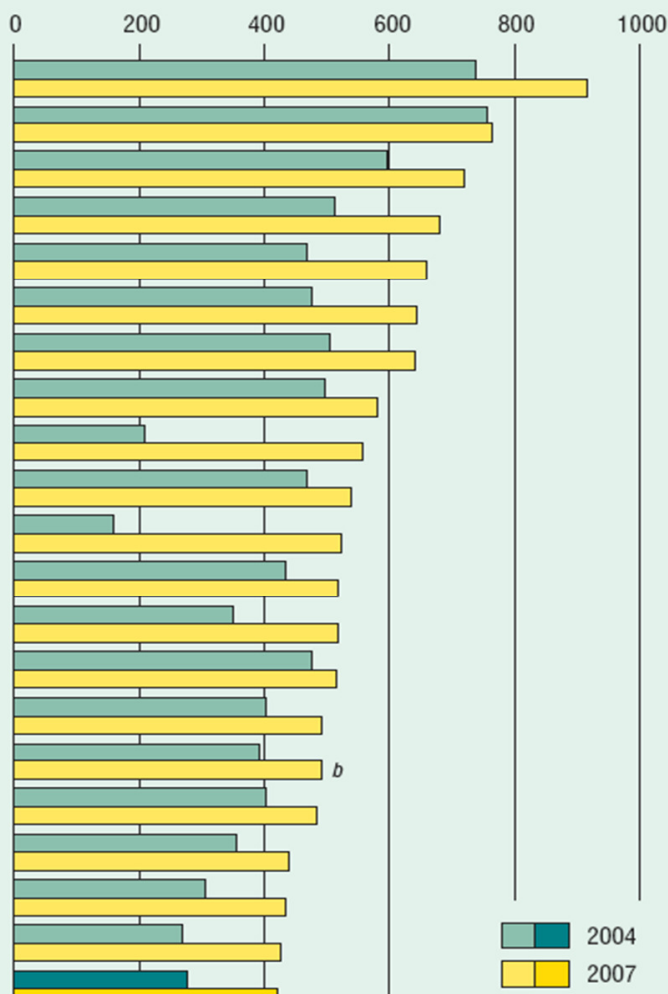

007

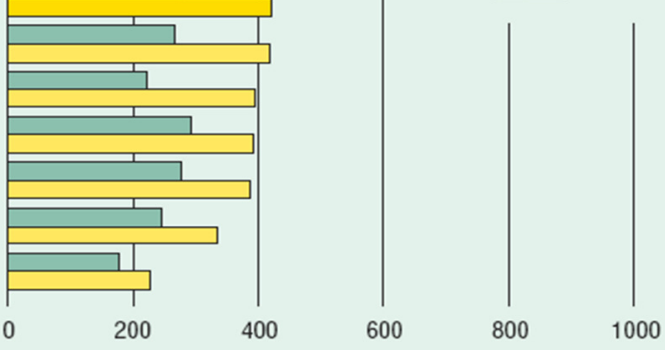

Source: Poland in the European... (2009). 
Figure 7. The employment rate for people aged 15-64 according to NUTS2 in 2007

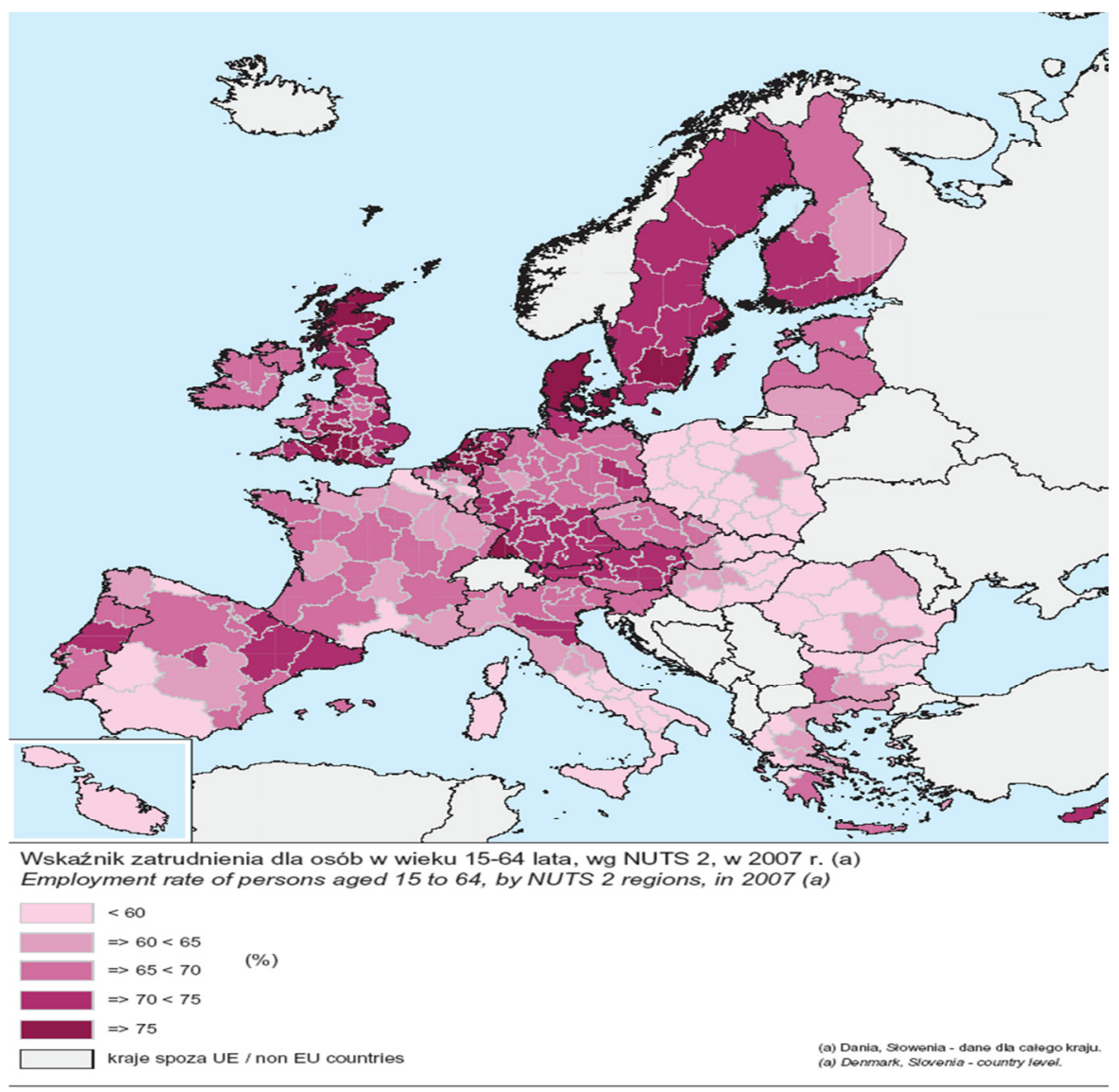

Source: Poland in the European... (2009).

Developing a long-term economic strategy of the country, especially in the period of systemic transformation during the economic crisis is a very difficult task, yet it is an indispensable and necessary tool for the proper functioning of the economy. The difficulty of developing an economic strategy of today is deepened by complicated international situation, global economic crisis, increasing unemployment and many global threats, for example ecology-related.

There are no empirical studies showing a correlation between the "development of a strategy" and economic success. However, even if the strategy does not guarantee the development itself, it at least increases the chances for the growth. This is simply because a strategy brings awareness of the need for change. The main benefit of a strategy is the opportunity to achieve 
coherence. In the case of countries where any consensus is very difficult to achieve, it is of great importance. In the absence of strategic planning during an unstable period, which is transformation, there is a drift of individual elements in the business defined by the directions, without regard to their role in the goal of system transformation. The availability of strategic aims and integrating impact of the process of their implementation makes the society move in a similar direction. This probably means both reducing the time to achieve certain goals, as well as reducing the costs of this process. The strategy becomes a link of general goal information between different elements and subjects of the economic system. The improvement in communication reduces the resistance to changes and allows for better understanding. It is almost impossible to involve people in participating in the change when they do not understand its purpose. A strategy can therefore be attributed to the following benefits (Hübner 1993, pp. 11-12):

- increasing the chance for survival

- increasing the chance for developing

- enhancing the cooperating

- improvement of communication

- reducing the resistance to change

- starting rational thinking process.

The fundament for rational action in terms of contemporary challenges should be the vision of future, which at the stage of professional thinking ought to be transformed into a socially acceptable development strategy (Stacewicz 2003, p. 70).

\section{COHESION AND ECONOMIC POLICIES*}

In the interpretation of EU regions there is a new vision of European integration, considering their independence and making local decisions closer to citizens, the inhabitants of these regions. The Single European Act (Rule 130A) states already that in order to promote the overall harmonious devel-

\footnotetext{
* In the context of EU subsidizing is possible to meet the concepts of regional policy, cohesion policy and structural policies. Structural policy is the traditional concept of the intervention of the European Communities (and since 1993 - the European Union) used since 1957. Regional policy is oriented towards increasing the economic and social cohesion in the European Union, which means that its primary function is financial aid for the regions. Cohesion policy indicates the first aim of the intervention which is the reducing disparities in the Community. Practically, however, these concepts are often used interchangeably and therefore can be assumed that regional policy, structural and cohesion policy of the European Union has the same aim - to reduce the economic disparities between EU regions and as a result - their residents.
} 
opment, the Community should act towards economic and social cohesion, in particular in the direction of reducing disparities between regions and tackling the backwardness of the less-favored regions. Within the frames of the EU regional policy, the regions are the main beneficiaries of structural funds aimed at aligning the existing disparities and the standard of living of their inhabitants.

In conditions of globalization and internationalization of economic life, the importance of competitive advantage of the particular regions as potential sites for doing business increases. The region may attract or discourage investors, depending on the attractiveness and competitiveness of its economic, social and environmental area. Regional structures take the part in the race for having lasting opportunities for accelerated development. The system of functioning of the region with its structure becomes a major strategic resource, which allows to get an advantage over other regions and to attract potential investors. In terms of integration and globalization the region becomes increasingly important for local and regional public good. The chance for regions lies in the ability to provide potential investors with a highly qualified workforce, an efficient study and research facilities, reliable infrastructure connecting the region with the world, a well-developed network of institutions supporting entrepreneurs, rich and diverse capabilities of collaboration with local firms. In today's economy, the region obtaining a competitive advantage, according to Gorzelak and Jalowiecki (Gorzelak, Jałowiecki 1998, p. 29) are the ones:

- easily accessible by a fast, reliable and flexible means of transport,

- with large research facilities,

- whose labor resources have high qualifications,

- which offer favorable life conditions and rich cultural environment,

- which have a well-developed base of so-called related services.

Six years have passed since Poland's accession to the European Union. In addition to obtaining new opportunities arising from accessing to the Community with legal and economic mechanisms, such as the Common European Market, and the partial opening of labor markets, the Poles became the direct beneficiaries of the EU budget: take an active part in European programs of cooperation in research and development areas, education, farmers and food producers benefit from the Common Agricultural Policy.

This part of the article is an attempt to reflect on the first effects of EU cohesion policy in Poland. This policy is aimed at supporting opportunities for growth in the poorest areas, as well as the ones having development difficulties of the EU, and offers a lot of opportunities for modernization and reducing the development gap for those who can use all the means by applying the appropriate socio-economic strategy to ensure their long-term impact. With such a large amount of potential financial resources devoted to 
cohesion policy, the question is whether the implemented strategy, programs and projects result directly in economic growth and create sustainable jobs, as well as provide structural change and modernization of the country? Some of the recently published analyses reinforce the skeptical evaluation of the role of the Structural Funds in economic growth of the countries and less developed regions (see Rodriguez-Pose, Fratesi 2004) and lead to the surprising conclusion that external aid can contribute to reducing the growth rate of such countries unless certain conditions occur (see Table 1). These are: the openness of the system to the environment and appropriate institutional infrastructure (see Ederveen, Groot, Nahuis 2006).

Table 1. Impact of the European Regional Development Fund funds on the European Union economy

\begin{tabular}{|l|c|c|c|}
\hline \multicolumn{1}{|c|}{ Country } & $\begin{array}{c}\text { Fund and insti- } \\
\text { tutional quality }\end{array}$ & $\begin{array}{c}\text { Fund and } \\
\text { corruption }\end{array}$ & $\begin{array}{c}\text { Fund and the open- } \\
\text { ness of the economy }\end{array}$ \\
\hline Austria & 1,71 & 1,01 & $-0,4$ \\
\hline Belgium & 2,03 & $-0,33$ & 1,84 \\
\hline Denmark & 2,01 & 2,93 & $-1,04$ \\
\hline Finland & 1,98 & 3,32 & $-1,9$ \\
\hline France & 1,49 & $-0,21$ & $-2,84$ \\
\hline Germany & 1,87 & 0,56 & $-2,55$ \\
\hline Greece & $-1,58$ & $-1,56$ & $-1,5$ \\
\hline Ireland & 0,24 & 0,44 & 0,93 \\
\hline Italy & 0,2 & $-1,43$ & $-2,9$ \\
\hline Luxembourg & 2,3 & 1,95 & 3,53 \\
\hline Netherlands & 2,17 & 2,14 & 0,76 \\
\hline Portugal & $-0,16$ & $-0,31$ & $-0,45$ \\
\hline Spain & $-0,31$ & 0,08 & $-2,25$ \\
\hline Sweden & 1,96 & 2,35 & $-1,49$ \\
\hline United Kingdom & 1,58 & 1,56 & $-2,16$ \\
\hline
\end{tabular}

Source: Ederveen, Groot, Nahuis (2006). 
Poland has had only six years of using funds marked for cohesion policy, in which the cohesion policy in 2004-2006 allocated over 16 billion euro ${ }^{1}$ and more than 85 billion euro in the period 2007-2013 2 .

Poland, which is now the largest beneficiary of the Structural Funds and Cohesion Fund of all Member States (nearly 20\% of the budget of cohesion policy for 2007-2013), is an excellent laboratory of the effectiveness of cohesion policy on many levels - macroeconomic, socio-economic, institutional. It is not possible to draw a final conclusion on the basis of expenditure incurred in the six years and fully documented findings on the effects of the strategy - you can only indicate some trends.

At the present economic development stage, known as brownfields, information or knowledge economy, one of the factors of rapidly growing importance in the development process is the information - as a carrier of knowledge and innovation. Knowledge and innovation are the main determinants of contemporary development, which is shaped where it is possible to obtain a competitive advantage through the ability to produce, develop and spread innovation as an engine of technological change, organizational and marketing. One of the conditions to achieve the Lisbon Strategy aims is a high level of innovativeness of enterprises, including an illustrated percentage of companies incurring expenditure on innovation activities. In Po$\operatorname{land}^{3}$, in the case of industrial enterprises employing over 49 people, this ratio in recent years did not exceed $40 \%$, showing no upward trend. Expenditures on innovation activities were usually related to the purchase of machinery and equipment and investments in buildings, while only about $9 \%$ of business expenditure on innovation was allocated to its own research. This is largely due to the fact that the independent conduct work on $\mathrm{B}+\mathrm{R}$ is seen by companies as a high-risk operation, which is combined with limited

${ }^{1}$ Including: 12.8 billion - the Structural Funds and Cohesion Fund, EUR 4 billion - the national public funds. In the years 2004-2006 were implemented the following operational programs: Sectoral Operational Programme Improvement of the Competitiveness of Enterprises (ERDF), the Sectoral Operational Programme Human Resources Development (ESF), the Sectoral Operational Programme Restructuring and Modernisation of the food sector and rural development (European Agricultural Guidance and Guarantee agriculture), SOP Fisheries and fish processing (Financial Instrument for Fisheries Guidance), Sectoral Operational Programme Transport (ERDF), the Integrated Regional Operational Programme (ERDF, ESF) and the strategy for the Cohesion Fund (Fund).

${ }^{2}$ Including: EUR 67.3 billion - the Structural Funds and Cohesion Fund; 11.9 billion national public funds, 6.4 billion eurro - private funds in 2007-2013 implemented operational programs are as follows: Operational Programme Infrastructure and Environment (ERDF and FS), Innovative Economy Operational Programme (ERDF) Operational Programme Human Capital (ESF), Operational Programme Development of Eastern Polish (ERDF) Operational Programme Technical Assistance (ERDF), European Operational Programmes for Territorial Cooperation (ERDF), the 16 Regional Operational Programmes (ERDF).

Regional development in Poland, Report 2009, Ministry of Regional Development, Warsaw 2009. 
financial capabilities of small and medium-sized enterprises in Poland, and generally causes large enterprises to engage in the conduct of their own research and development works. The total amount of expenditures incurred by enterprises in different provinces is quite strongly correlated with the level of development of the region and measured by GDP per capita by $\mathrm{PPS}^{4}$. The correlation coefficient reaches 0.79 , which indicates that it's usually in the wealthier regions of the country that companies are more likely to bear such expenses than in the case of companies from poorer regions.

Map 1. Structure of the marked financial resources by groups of intervention category (the end 2006)

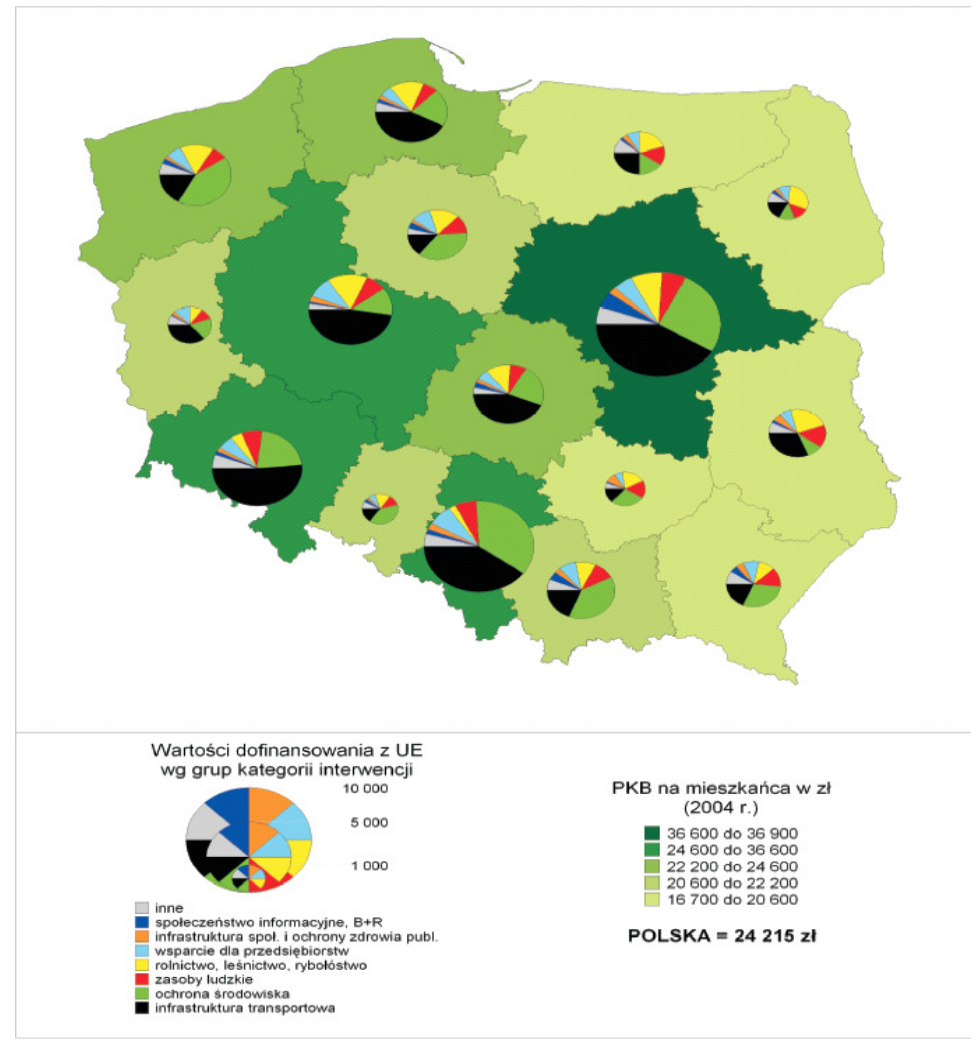

Source: Review of Regional No. 2, Ministry of Regional Development, Warsaw, September 2008.

${ }^{4}$ In the contractual currency units that eliminate the impact of differences in purchasing power of currencies (PPS Purchasing Power Standards). 
An important factor of economic growth is capital expenditure, affecting the productive capacity of enterprises and their technological upgrades, often accompanied by higher efficiency, better product quality, greater ability to export, increasing stuff qualifications and skills. In addition, the number of created jobs depends on the volume and type of investment. The period 2000-2007, except 2004, resulted in the weakening of investing activities and the following decline in investments. In 2007, in the enterprise sector outlays for investments grew by only $3 \%$ (current prices) in relation to the year 2006. The average share of private sector investment in capital expenditures in Poland was $68 \%$ per capita in 2007. In discussing the macroeconomic situation especially noteworthy is the decline in the unemployment rate, which lasted until 2009. When considering the use of human capital, a number of negative interrelated phenomena should be noted, which are permanent features of the Polish labor market. Most of all, these include the low level of economic activity, represented by an employment rate of $57 \%$, one of the lowest in the EU (EU average is over 65\%).

Polish membership in the European Union has not affected significantly the improvement of the situation in science and technology so far, because investments in research - development works in Poland, still represent only $0.57 \%$ of GDP. This places Poland among the countries with one of the lowest levels of funding for science in the European Union (more: Gąsowski, 2010).

The data in Table 2 shows that a lot of projects are realized in Poland. However, they are too scattered, small, local, infrastructured, therefore a questionable as for the impact on the competitiveness of the region and country. Table 3 confirms that the Polish economy is not among the competing economies in the light of international comparisons and rankings.

Table 2. Number of signed contracts for the financing, the total value of Community assistance resulted from the signed agreements and the support value per capita - at the end of July 2005

\begin{tabular}{|l|c|c|c|c|c|}
\cline { 2 - 5 } \multicolumn{1}{c|}{} & \multicolumn{2}{c|}{ TOTAL } & \multirow{2}{*}{ Population } & $\begin{array}{c}\text { The value of the } \\
\text { aid per capita } \\
\text { (PLN) }\end{array}$ & $\begin{array}{c}\text { Relation to } \\
\text { the average } \\
\text { value for the } \\
\text { country (\%) }\end{array}$ \\
\hline dolnośląskie & 318 & 462458989 & 2895729 & 231,92 & $\mathbf{6 8 , 7 2}$ \\
\hline $\begin{array}{l}\text { Kujawsko- } \\
\text {-Pomorskie }\end{array}$ & 292 & 603642930 & 2067548 & 364.18 & $\mathbf{1 0 7 , 9 1}$ \\
\hline Lubelskie & 403 & 489717498 & 2187918 & 296.05 & $\mathbf{8 7 , 7 2}$ \\
\hline Lubuskie & 206 & 338331691 & 1009177 & 407.47 & $\mathbf{1 2 0 , 7 4}$ \\
\hline
\end{tabular}


Table 2 Continued

\begin{tabular}{|l|c|c|c|c|c|}
\cline { 2 - 5 } \multicolumn{1}{|c|}{} & \multicolumn{2}{|c|}{ TOTAL } & \multirow{2}{*}{ Population } & $\begin{array}{c}\text { The value of the } \\
\text { aid per capita } \\
\text { (PLN) }\end{array}$ & $\begin{array}{c}\text { Relation to } \\
\text { the average } \\
\text { value for the } \\
\text { country (\%) }\end{array}$ \\
\hline Lódzkie & 280 & 419455893 & 2592568 & 234,01 & $\mathbf{6 9 , 3 4}$ \\
\hline Małopolskie & 46 & 534067904 & 3256171 & 236.24 & $\mathbf{7 0 , 0 0}$ \\
\hline Mazowieckie & 708 & 1269706171 & 5139545 & 319.27 & $\mathbf{9 4 , 6 0}$ \\
\hline Opolskie & 205 & 224428208 & 1053723 & 285.20 & $\mathbf{8 4 , 5 1}$ \\
\hline Podkarpackie & 372 & 568995171 & 2097325 & 343.51 & $\mathbf{1 0 1 , 7 9}$ \\
\hline Podlaskie & 350 & 313019080 & 1204036 & 332.19 & $\mathbf{9 8 , 4 3}$ \\
\hline Pomorskie & 770 & 1097344483 & 2192404 & 572.74 & $\mathbf{6 9 . 7 1}$ \\
\hline Śląskie & 501 & 1119144088 & 4707825 & 309.94 & $\mathbf{9 1 , 8 4}$ \\
\hline Świętokrzyskie & 305 & 335063300 & 1290176 & 331.92 & $\mathbf{9 8 , 3 5}$ \\
\hline $\begin{array}{l}\text { Warmińsko- } \\
\text {-Mazurskie }\end{array}$ & 411 & 592988857 & 1428385 & 487.37 & $\mathbf{1 4 4 . 4 1}$ \\
\hline Wielkopolskie & 431 & 1003930639 & 3362011 & 370.83 & $\mathbf{1 0 9 , 8 8}$ \\
\hline $\begin{array}{l}\text { Zachodniopo- } \\
\text { morskie }\end{array}$ & 755 & 755349817 & 1695708 & 517.67 & $\mathbf{1 5 3 , 3 9}$ \\
\hline Country level & 13297 & 2757326430 & 38180249 & 72.22 & - \\
\hline $\begin{array}{l}\text { TOTAL/ AVER- } \\
\text { AGE }\end{array}$ & $\mathbf{2 0 ~ 0 6 5}$ & $\mathbf{1 2} \mathbf{8 8 4} \mathbf{9 7 1} \mathbf{1 4 6}$ & $\mathbf{3 8 ~ 1 8 0 2 4 9}$ & $\mathbf{3 3 7 . 4 8}$ & $\mathbf{1 0 0 . 0 0}$ \\
\hline
\end{tabular}

Source: The first period of use of structural funds in Poland, Report MA CSF, Warsaw, September 2005, p. 8.

Table 3. Ranking by Global Competitiveness Index (GCI)

\begin{tabular}{|c|c|c|c|c|c|c|c|c|c|}
\cline { 2 - 9 } & Britain & Germany & France & Spain & Lithuania & $\begin{array}{c}\text { Czech } \\
\text { Republic }\end{array}$ & Italy & Slovakia & Poland \\
\hline $\begin{array}{c}\text { Ranking } \\
\mathbf{2 0 0 8 -} \\
\mathbf{2 0 0 9}\end{array}$ & 12 & 7 & 16 & 29 & 44 & 33 & 49 & 46 & 53 \\
\hline $\begin{array}{c}\text { Ranking } \\
\mathbf{2 0 0 9 -} \\
\mathbf{2 0 1 0}\end{array}$ & 12 & 7 & 16 & 33 & 53 & 31 & 48 & 47 & 46 \\
\hline
\end{tabular}

Source: DAP MG on the basis of The Global Competitiveness Report 2008-2009, 2009-2010. 
In the future it will be necessary to ensure that the regions concentrate national and EU resources on a small number of priorities, responding to specific challenges that must be faced. This can be achieved by defining in the rules of cohesion strategy the limited number of thematic priorities related to the integrated, guidelined priorities and guiding projects which were announced in the strategy of "Europe 2020".

\section{CONCLUSIONS}

Although globalization is a driving force for social, economic, and political changes (Liberska 2002, pp. 25-27), it is also a serious shock for societies, national economies and the global economy, which creates a great opportunity for development, but on the other hand is a serious threat. It seems that a basic condition for reaping the benefits of globalization is a complete involvement in the mainstream. Poland, like other countries of Central and Eastern Europe, should lead a policy open to globalization, aimed at increasing the benefits and minimizing the risks of globalization. It should include mainly:

- building a strong, modern and competitive market economy, which is efficiently managed at all levels of administration;

- the gradual liberalization of the capital market after reaching financial stability, so as to eliminate potential threats;

- quality and way of administrating (governance).

In the context of globalization, recent researches are especially valuable: on the subject of the relationships between quality of governance and openness of the economy, the creation of institutions protecting the economy against corruption and supervising the quality of governance and progress in reforming the economy (more: Wojtyna 2001).

Building the competitiveness of the regions require a strategic look at the development and a dynamic approach to regional policy. The responsibility for the creation and implementation of this policy largely lays on the representatives of regional and local authorities. Using the strategic number of instruments, it is possible to stimulate the behavior of regional subjects, implementing own potential and identify needed development directions. These capabilities enhances not only the state's regional policy, but primarily the shape and rules of the new EU regional policy for 2007-2013. Appropriately shaped regional politics, understanding its mechanisms and gain the ability to use the assistance offered by the EU Structural Funds is a challenge and also an opportunity for the development of Polish regions.

Financing of regional policy in Poland substantially absorbs budgetary resources and its effects are much more modest than those intended. The 
main purpose of the regional policy of reducing the development gap between the richest and poorest regions, has been only partially realized. The globalization requirements are forcing the ongoing reforms of regional policy. A fundamental dilemma arises: whether to continue to provide important support for poor regions, or should we spend more on research, development and increasing the competitiveness of the Polish economy? The second option is to give more resources to the richest regions in order to improve the economic situation of the country as a whole. This problem has been partially solved in the Union financial perspective for 2007-2013 in favor of the twenty-first century challenges. It is easy to notice that the resources marked for researches, development and increasing the competitiveness are too modest in relation to the demands and new goals which were set by European Union. As a result, there has been no fundamental shift in financial policy of the regional UE policy. Financing the regional policy still will be the priority area of the Community's activity, the aid will have to be used more effectively, with particular emphasis on increasing the competitiveness of regions, which would allow backward regions to meet the demands of globalization.

Effective use of financial resources of European regional policy depends on several groups of factors (Kozak 2006, p. 75):

- the theoretical fundaments and development model of the country,

- development strategy (and operational documents) resulting from the above,

- the country's institutional system,

- management system of the regional policy.

Although strategy documents of regional policy in Poland declaratively include measures to promote the modern economy development, in large part, as practice shows, these records remain only declared or are implemented in a marginal way. An analysis of spending trends in the European Cohesion Policy leads to the conclusion that the policy was implemented to achieve alignment and consistency level especially in the social sphere. However, it was much less successful with achieving the willingness to long-term development of a competitive economy declared in strategic documents. The implementation of structural policy in the years 2004-2008 more contributed to the improvement in quality of life than to creating longterm basis for the development.

The main challenge for the Polish regions in the early twenty-first century is the optimal use of development potential to ensure lasting and sustainable development, increase economic competitiveness and social-economic cohesion, but also to meet global challenges such as population ageing, energy and climate change, also financial and economic crisis, which global economy currently faces. Attaining these objectives requires: 
- developing a long-term socio-economic strategy;

- creating the conditions for proper use of regions own resources(endogenous factors);

- attracting external resources and directing them on task realization;

- with most growth potential, using the instruments of public policies, including cohesion policy instruments.

Looking from the perspective of today's internal and external challenges, we can say that the development possibility of Polish regions depend mainly on:

- development of regional specialization using endogenous growth potential and attracting external resources - internal and foreign investment, innovative companies, skilled workforce;

- human capital ability to develop knowledge and skills (necessary to adapt to changing circumstances) and their use in economic processes;

- manufacturing, development and innovation diffusion skills as determinants of contemporary development;

- institutional administration capacity to manage the development.

The approach to the most important factors of development changes not only according to theoretical models, but also depending on the stage of development of individual economies and societies. There has been an evolution over the centuries from the recognition of natural resources as a basis for development, through the capital and political power, technology and knowledge to the currently formulated hypotheses, which recognizes the causes of development in institutional and cultural factors (Gorzelak 2007, p. 184). Currently, the need for fundamental change in the economic policy paradigm is becoming more and more evident, including regional-level through goals, strategies, tools, areas of impact and the main subjects of regional ${ }^{5}$ policy. It involves shifting the focus from exogenous growth factors (external investments, transfers) on endogenous resources and potential and abandon the traditional approach that compensates the unfavorable situation of underdeveloped regions through the support of sectoral or income redistribution to the use of comparative advantages of each region in order to strengthen their competitiveness. A new concept of regional policy emphasizes an integrated approach to development, directing investment - apart from strengthening the technical infrastructure and the labor market, also to promote the business environment, social capital and networking relationships, and stresses the need to realize multi-level governance and consider-

${ }^{5}$ Policy report, TDPC Meeting at ministerial level (31 March 2009), Public Governance and Territorial Development Directorate, Territorial Development Policy Committee, OECD, GOV/TDPC(2008)10/REV1, 30.01.2009. 
ing the functional territories as the recipient policy, apart from the areas limited by administration.

Internal determinants of regional development in Poland and the modern global challenges, as the recession caused by financial crisis, demographic processes, climate and energy sector changes, reveal the need to consider widely the elements of this new regional policy paradigm - knowledge and innovation as key factors for the development and directing activity on strengthening the endogenous potentials of all regions in order to increase their competitiveness, and thus generate growth at the national level.

\section{LITERATURE}

Czapiński U, Panek T. (2009), Social Diagnosis 2009, conditions and quality of life for the Poles, Report, Warsaw.

Ederveen S., de Groot H.L.F., Nahuis R. (2006), Fertile Soil for Structural Funds? A Panel Data Analysis of the Conditional Effectiveness of European Cohesion Policy, "Kyklos", Vol. 59, No. 1.

Gąsowski A. (2010), Polish science against the background of the European Union, Report, http://realia.com.pl/pdf/1_2010/02_01_2010.pdf.

Gorzelak G. (2007), Development - Region - Politics, [in:] Gorzelak G., Tucholska

A. (ed.), Development, region, space, Ministry of Regional Development. Centre for European Regional and Local Studies EUROREG UW, Warsaw.

Gorzelak G., Jałowiecki B. (1998), Dilemmas of European [in:] Buczkowski P., Bondyra K., Sliwa P. (ed.), What is Europe? Regionalization and integration, Poznań.

Hübner D. (1993), Strategy development: conceptual considerations and models, reports, "Studies on strategy", Warsaw .

Kanthak A. (2007), Poland needs a unified strategy, "Pomeranian Economic Review", No. 5

Kozak M.W. (2006), The governance of regional policy in Poland in the first period after accession, "Regional and Local Studies" No. 2(24).

Liberska B. (2002), Globalization. Mechanisms and challenges, PWE, Warsaw.

The first period of use of structural funds in Poland (2005), Report MA CSF, Warsaw, September.

Poland in the European Union (2009), GUS, Warsaw.

Regional Overview No. 2 (2008), Ministry of Regional Development, Warsaw, September.

Policy report, Meeting at ministerial TDPC level (2009), Public Governance and Territorial Development Directorate, Territorial Development Policy Committee, OECD, GOV / TDPC (2008) 10/REV1, 30/01/2009.

Rodriguez-Pose A., Fratesi U. (2004), Between Development and Social Policies: The Impact of European Structural Funds in Objective 1 Regions, "Regional Studies", Vol 38, No. 1. 
Regional development in Poland (2009), Report 2009, Ministry of Regional Development, Warsaw.

Smolski R., Smolski M., Stadtmüllero E.H. (2009), Encyclopedic Dictionary of Civic Education, Publishing Europe.

Sulmicka M. (2004), Programming strategy development in Poland and the European Union, RCSS, Warsaw.

Stacewicz J. (2003), Towards metaeconomy, SGH, Warsaw.

Wojtyna A. (2001), New directions of research on the economic role of the State, "Economist", No. 1. 